\title{
EVALUATING MANAGERS DIVERSIFICATION OF REAL ESTATE PORTFOLIOS: EVIDENCE FROM NIGERIA
}

\author{
Abel OLALEYE $1 \bowtie$ and Bioye Tajudeen ALUKO ${ }^{2}$ \\ 1 Department of Estate Management, Obafemi Awolowo University, Ile - Ife, Nigeria \\ E-mail: a_olaleye2000@yahoo.co.uk \\ 2 Department of Estate Management, Obafemi Awolowo University, Ile - Ife, Nigeria \\ E-mail: btaluko@oauife.edu.ng
}

Received 20 November 2006; accepted 12 June 2007

\begin{abstract}
While there is evidence on the effectiveness of diversifying real estate portfolio geographically, or by property type, there is lack of empirical evidence to justify whether diversification of managers is worth pursuing. This study produces evidence on the effectiveness of diversifying by managers and property types. The study collected data on capital and annual rental values from three (3) main Property Investment and Development Companies in Lagos Metropolis, Nigeria. From the data so collected, annual total returns (IRR), on residential properties, for a period of between 1997 and 2001 on the managers' portfolio were calculated. Under the assumptions that investments are held long and that constant correlation model or excess return to standard deviation represents the covariance structure of assets' returns, the study's analyses suggest that diversification of managers and property types produce improved performance. It also opens the possibility that an efficient portfolio developed by using constant correlation analysis may not be more efficient than a naively diversified portfolio as some of the naive diversification strategies are found to be effectively efficient.
\end{abstract}

KEYWORDS: Evaluation; Managers diversification; Real estate portfolio; Constant correlation model; Naive diversification

\section{INTRODUCTION}

Throughout the ages, investors have approached the problems of investment decision in a number of ways. Some prefer the strategy, which according to Hargitay and Yu (1993) was formulated by Andrew Carnegie, whose maxim says "put all your eggs in one basket and then watch the basket". The dictum "do not put all your eggs in one basket" appears to be the belief of many. Hence, the idea that the risk of loss can be minimised by not putting all of one's assets in "one basket" has been around for a very long time. Since Markowitz $(1952,1959)$ foundation works on Modern Port- folio Theory (MPT), authors and professionals have examined almost every possible ways of diversifying within the stock market although two decades elapsed before MPT was first applied to real estate. Attempts to transplant this methodology have long been frustrated due to the peculiar nature of property market, especially the lack of adequate time-series data. Meanwhile, the first research began in early 1980s (quoting from Mueller, 1993) with the presumption that a properly diversified real estate portfolio should help to partially overcome the illiquidity and mobility problems inherent in real estate.

Studies such as, Hadaway, (1978); Miles and

International Journal of Strategic Property Management ISSN 1648-715X print / ISSN 1648-9179 online @ 2007 Vilnius Gediminas Technical University http://www.ijspm.vgtu.lt 
McCue, (1982); Hartzell, Hekman and Miles, (1986); Grissom, Kuhle and Walther, (1987); Giliberto and Hopkins, (1990); Mueller, (1993); Pagliari, Webb and Del Casino, (1995); Brown, (1997); Brown, Li and Lusht (2000); Conover, Friday and Sirmans (2002); Lee (2005); Lee and Stevenson (2005) and Adair, McGreal and Webb (2006) have generally demonstrated that diversification benefits may be captured by combining different classes of real estate assets in different locations or by acquiring different property types or using both strategies. In other words, real estate diversification has traditionally been studied along two dimensions, namely, geographic/economic grouping and property types. However, the comment of Cheng and Liang (2000) on diversification of managers and property types as well as the results of Ajala (2001), in Nigeria, opened the question of whether diversification by managers and property types would produce comparable (or improved) performance. The answer to this question is necessary because authors such as Del Casino, (1995), Olaleye (2000) and Ajala (2001) have noted the importance of differing managerial skills on the overall performance of property portfolios.

The concept of managers and property type diversification holds that investors may combine investments and achieve good portfolio performance by investing in various property types focusing on the different management firms. The idea derives from the fact that the varying skills and experiences possessed by various property managers can have influence on the performance of a particular property or portfolio in terms of risk-return trade-off. In addition, it is believed that the differences among property types relate to the time and expertise necessary to manage them as investments. Thus, Cheng and Liang (2000) reported that pension funds in U.S.A. have been advised to seek diversification of managers and property types.

Since early 1980s, studies were conducted with various techniques and databases used to examine the benefits of diversifying real estate geographically and by property types. They were also based on a variety of levels including national, regional, metropolitan areas, and even smaller spatial definitions. Miles and McCue (1982) tested diversification strategies in United States of America by dividing the country into four geographic regions and comparing this with a strategy that diversified the portfolio by property types. They found out that diversification by property type showed better risk return characteristics than did a four region geographic strategy. In the same vein, Hartzell, Hekman and Miles (1986), Hartzell, Shulman and Wurtzebach (1987), Grissom, Kuhle and Walther (1987), Giliberto and Hophins (1990) and Mueller (1993) studies examined efficient frontiers for various diversification schemes and compared them against naively diversified portfolios. The studies found evidence (although mix evidence) to show that geographic and or property type diversification brings marginal improvement in portfolio performance. Besides, Pagliari, Webb and Del Casino (1995) findings suggest that while MPT yields optimal ex post portfolios, its use as an ex ante portfolio allocation strategy can lead to mixed results. Cheng and Liang (2000) improved on pervious studies on optimal diversification by answering few questions that centred on whether improvement is significant in a statistical sense or not. The study found evidence to support the fact that an efficient portfolio is statistically more efficient than a corresponding naively diversified portfolio when the portfolio period is the same as the period used for testing the difference in efficiency. Brown, Li and Lusht (2000) study on intracity geographic diversification divide Hong Kong into sub-markets and concluded that efficient portfolios outperform many naive strategies based on equal allocations across districts, and outperform most, but not all, of those based on "all your eggs in one district" 
strategies. Viezer (2000) found evidence to suggest, among others, that more dimensions of diversification are better than fewer dimensions and that the best strategy used sixteen dimensions (four property types in four geographic regions). Recent studies such as Steinert and Crowe (2001), Conover et al. (2002), Lee (2005), Liow, Ooi and Gong (2005) and Lee and Stevenson (2005) have also evaluated and determined the benefits of diversification from both local and foreign/global real estate investments. Adair, McGreal and Webb (2006) also established the diversification effects of direct versus indirect real estate investment in U.K. These studies have shown that different diversification strategies come with different portfolio benefits.

The above, no doubt, is a pointer to the fact that there are many empirical studies justifying whether diversification by property types or by geographic or economic location is worth pursuing. With managers and property type diversification, little is known. Thus, this paper has found the justification for examining the effectiveness of managers diversification, more so that authors such as Del Casino (1995) have noted that investing in various property types based on the differing managerial skills could bring improved performance. Cheng and Liang (2000) reported that pension fund in U.S.A. have been advised to seek diversification of managers and property types. Olaleye (2000) is of the opinion that good management decisions, as a reflection of management style, could have enormous influence on the performance of property portfolios. Also, Ajala (2001) results on comparative performance measurement of public and private real estate portfolios (firms) suggest that management style adopted by firms is very significant to the performance of their property portfolios. Specifically, the study found evidence to suggest that differing management styles and skills can bring differing portfolio performance. All these point to the fact that there may be some ben- efits derivable from managers' diversification. The central theme of this paper therefore is to examine the question of whether diversification by managers and property types would produce better performance.

\section{METHODOLOGY AND DATA}

The benefits of managers diversification are measured in real estate market of Ikoyi and Victoria Island areas of Lagos Metropolis, Nigeria. This is done with the belief that if benefits of managers diversification can be measured in these relatively homogenous markets, then they are likely to be found elsewhere. The sample is annual transaction data for residential properties obtained from three major property investment and development companies in Nigeria for five-year period from 1997 through 2001. These companies are WEMABOD Estate Limited, UACN Property Development Company and Stallion Property Development Company. This period, in the Nigerian property markets, can be divided into two sub-periods. These are (i) 1997 to 1999, which is characterised by expansion and positive growth in most of the Nigerian markets and (ii) 2000 to 2001, which reflects the beginning of contraction phase following the positive growth in rent, positive but slow growth in demand and the greater than demand increasing supply. The scope of the study was restricted to a consideration of diversification options within residential property sector only. Also, the properties included in the sample were those located within Ikoyi and Victoria Island property markets in Nigeria. This restriction in scope is done in a concerted effort to control or remove the gains that may be obtained from investing in different property sectors and locations. This thus limits our consideration of the benefits of diversification to different manager's skills.

The managers of the three companies sampled were asked to give data on performance 
levels of residential properties, located in the study areas in their respective portfolios in aggregated form. In other words, the study adopted aggregated approach on properties' performance with the performance of each property type sampled reflecting the average performance level of all the individual property type contained in each manager's portfolio. This reduction in scope is necessary because property companies in Nigeria prefer giving out needed data on properties' performance levels in aggregated form rather than on an individual basis for confidential reason. Although, this methodology, according to Geltner (1991), tends to understate the volatility of the real estate market especially because the property values are appraisal based, the author opined that the bias becomes a systematic error since it has a similar impact on all the properties included in the analysis.

Annual internal rate of returns on each of the property type and in each of the three managers' portfolios were estimated as:

$$
\begin{aligned}
& C_{0}=\frac{R_{1}-P_{1}}{\left(1+r_{m}\right)^{1}}+\frac{R_{2}-P_{2}}{\left(1+r_{m}\right)^{2}}+\ldots \frac{R_{t}-P_{t}}{\left(1+r_{m}\right)^{t}} \ldots \ldots+ \\
& \frac{C_{n}+\left(R_{n}-P_{n}\right)}{\left(1+r_{m}\right)^{n}}
\end{aligned}
$$

where: $r_{m}$ is the internal rate of return (IRR); $R_{t}$ is the income received in period $t, t=1,2$, $3, \ldots n ; P_{t}$ is the net purchase/outlays in pe$\operatorname{riod} t, t=1,2,3, \ldots n ; C_{n}$ is the value of the property at the end of period $n$ (measurement period); $C_{0}$ is the initial cost of investment or capital value of the asset at the beginning of the measurement period; $n$ is the number of time-period (measurement period).

The result is a return series for each of the managers named A, B, C (see Table 1) from which optimal (efficient) portfolios were constructed using constant correlation model. The calculations were based on the assumption that investments are held long. The use of this method is preferred to the traditional mean variance analysis because of its reduced math-

Table 1. Average Return Statistics per annum (\%) (1997-2001)

\begin{tabular}{cllll}
\hline Property type & & Manager A & Manager B & Manager C \\
\hline 2 Bedroom flats: & Mean $\left(R_{i}\right):$ & 22.70 & & \\
Property 1 & Std. $(\delta):$ & 2.381 & ------ & \\
& $\left(R_{i}-R_{f}\right) / \delta:$ & 3.494 & & \\
3-4 Bedroom bungalow: & Mean $\left(R_{i}\right):$ & 16.55 & & \\
Property 2 & Std. $(\delta):$ & 1.321 & ------ & \\
& $\left(R_{i}-R_{f}\right) / \delta:$ & 1.643 & & \\
3-4 Bedroom duplexes: & Mean $\left(R_{i}\right):$ & & 11.12 & 23.75 \\
Property 1 & Std. $(\delta):$ & ------ & 1.719 & 0.891 \\
& $\left(R_{i}-R_{f}\right) / \delta:$ & & -1.896 & 10.516 \\
3-4 Bed detached house: & Mean $\left(R_{i}\right)$ & & 24.49 & 19.76 \\
Property 2 & Std. $(\delta):$ & ------ & 1.387 & 1.685 \\
& $\left(R_{i}-R_{f}\right) / \delta:$ & & 7.289 & 3.194 \\
3-4 Bedroom flat: & Mean $\left(R_{i}\right)$ & & 11.77 & 22.38 \\
Property 3 & Std. $(\delta):$ & ------ & 0.430 & 2.620 \\
& $\left(R_{i}-R_{f}\right) / \delta:$ & & -6.070 & 3.053 \\
\hline
\end{tabular}

Note: $R_{f}$ (the average returns on Treasury bills for the period) $=14.38 \%$.

The three managers' identities are not disclosed in this paper due to confidentiality attached to information in the Nigerian property market. 
ematical complexities. Thus, it allows a portfolio manager to quickly and easily determine the optimum portfolio without much mathematics as in Markowitz's mean variance model. Besides, it is the expectation that the Nigerian investors will support a less complex analysis since, like other investors, they are loath to invest on the basis of allocation system that they do not understand. Also, it is the authors' belief that mean variance analysis is best suited for a developed real estate market where there is evidence of time-series data and investments can be held short. Where property market is yet to be fully integrated into the capital market operations and most investments are held long, such method as mean variance analysis can produce misleading results. In addition, the use of constant correlation model also allowed us to single out just six portfolios for testing against the naive portfolios and thus we do not have to test every single efficient portfolio which, off-course, is infinite in number. The six portfolios tested were based on $+1,+0.5,+0.1,-0.1,-0.5$ and -1 correlation coefficients between each pair of asset.

The procedure for this model as described by Elton and Gruber (1981) involved, basically, three steps. First, assets are ranked by their excess return to standard deviation as:

$$
\left(R_{i}-R_{f}\right) / \delta_{i}
$$

Second, a cut-off rate $C^{*}$ which determines how many assets are selected in the optimal portfolio, will be fixed by first calculating the cut-off rate $C_{i}$ for each assets as thus:

$$
C_{i}=\frac{\rho}{(1-\rho+i \rho)} \times \frac{\sum_{j=1}^{i}\left(\overline{R_{i}}-R_{f}\right)}{\delta_{i}},
$$

where: $\rho=$ the correlation coefficient - assumed constant for all securities; $C_{i}=$ calculated cutoff rate for asset $i$.
The cut-off rate $\left(C^{*}\right)$ is then fixed such that all assets/properties with higher ratios of $\left(R_{i}-R_{f}\right) / \delta_{i}$ than their $C_{i}$ will be included in the optimal portfolio and all assets with lower ratios excluded. Third, the optimal amount, which must be invested in each asset, is calculated as:

$$
X_{i}^{0}=\sum_{i=1}^{n} \frac{Z_{i}}{Z_{i}}
$$

where: $Z_{i}=\frac{1}{(1-\rho) \delta} \times\left\{\frac{\left(R_{i}-R_{f}\right)}{\delta}-C^{*}\right\}$.

Following from the procedures described above, optimal portfolios are constructed and their efficiency compared with the various naive portfolios developed so as to determine the superiority or otherwise of the naive diversification schemes. These naive diversification portfolios are based on:

1. Equal allocation between managers (1 portfolio).

2. All investment in one manager (3 portfolios).

3. Equal allocation between managers with the allocation to each manager spread evenly among the property types in the manager's portfolio (1 portfolio).

4. Equal allocation between managers with the allocation to each manager invested in one property at a time (13 portfolios).

In all, 18 different naive diversification portfolios were considered and their mean/standard deviation ratio as well as effectiveness of diversification compared with the efficient portfolios.

The mean standard deviation criterion holds that portfolio A from strategy $\mathrm{X}$ is better than (or dominate) portfolio B from strategy $\mathrm{Y}$ if $M / \delta\left(P_{a}\right)>M / \delta\left(P_{b}\right)$. A higher ratio is associated with higher portfolio efficiency. In addition, portfolio efficiencies are viewed in terms of their effectiveness of diversification meas- 
ure. This expresses the percentage reduction in risk achieved by holding a variety of different assets, which is borne out of the fact that in modern portfolio theory, the risk of a portfolio, as measured by the standard deviation of returns, is less than the weighted average risk of the individual constituent assets. Thus, by comparing the risk of portfolio return $(R)$ with the weighted average risk of individual assets $(W)$, it should be possible to produce a measure of the effectiveness of diversification (Ajayi, 1998 quoting Lumby, 1984). It is measured as:

$$
\text { Effectiveness of Diversification }=(W-R) / W \text {. }
$$

The higher the ratio, the higher the efficiency of diversification.

\section{RESULTS}

In the study, 18 different naive portfolios were constructed for use as benchmark. They are based on:

(1) Diversification by manager (wherein property purchase is not given consideration) and where investments were either solely in one manager (3 portfolios) or in equal allocations to each of the three managers ( 1 portfolio).

(2) Diversification of managers and property types wherein property purchases are considered. Here, we considered (a) equal allocation to managers with the allocation assumed to spread evenly among the property types in each manager's portfolios (1 portfolio), and (b) equal allocation to managers with the allocation to each manager invested in one property type at a time ( 13 portfolios). Table 2 presents the returns (and standard deviations) of these benchmark portfolios. The results show that they range from $15.79(0.274)$ to 21.96 (1.154) for managers' diversification only and 15.81 (0.253) to 23.65 (1.258) for managers and property types diversification. Returns and risks tended to be higher for managers and property types diversification than for manager diversification only. Also, the diversification strategies of equal allocation across managers and property types with the allocation invested in one property type in each manager's portfolio produced a better (dominant) portfolio with the strategy of diversifying equally across managers and property types ranking second. The diversification strategy of equal allocation to each manager's portfolio ranked third in efficiency level, in terms of mean/standard deviation ratio.

\subsection{Residential Diversification by Manager (Efficient Portfolios)}

The results of diversification by manager are shown in Table 3. The results include the standard deviation, mean returns, weights mean/standard deviation ratio and effectiveness of diversification of the six efficient portfolios constructed. Among these portfolios, the portfolio that is based on correlation coefficient of 0.1 produced dominant results in terms of mean/standard deviation ratio and effectiveness of diversification. Also, the range of results is less than those realised for naive diversification strategies. Range of results is 4.07 vs 6.17 for efficient and naive portfolios respectively. It is also noted that the dominant portfolio (in terms of mean/standard deviation ratio) outperformed the naive diversification based on this strategy but has a lower effectiveness of diversification of 0.6206 as against the naive diversification effectiveness of 0.6684 . One other thing noted in these results is that, on the average, portfolio efficiency tends to increase with the reduction in the correlation coefficient.

\subsection{Residential Diversification by Managers and Property Types}

The returns, standard deviation and weight of efficient portfolios as well as their mean/ 
Table 2. Returns and Standard Deviation of Benchmark Portfolios

\begin{tabular}{|c|c|c|c|c|c|}
\hline \multicolumn{2}{|l|}{ Strategies } & $\begin{array}{l}\text { Portfolio } \\
\text { Return }\left(R_{p}\right)\end{array}$ & $\begin{array}{l}\text { Standard } \\
\text { Deviation (Std) }\end{array}$ & $\begin{array}{l}\text { Eff. of } \\
\text { Diversification }\end{array}$ & $\begin{array}{l}\text { Mean/Std } \\
\left(R_{p} / \delta\right)\end{array}$ \\
\hline \multicolumn{6}{|c|}{ Manager Diversification Only } \\
\hline \multicolumn{2}{|c|}{ All investment funds in Manager A } & 19.63 & 0.878 & 0.5257 & 22.358 \\
\hline \multicolumn{2}{|c|}{ All investment funds in Manager B } & 15.79 & 0.294 & 0.7506 & 53.708 \\
\hline \multicolumn{2}{|c|}{ All investment funds in Manager C } & 21.96 & 1.154 & 0.3337 & 19.029 \\
\hline \multicolumn{2}{|c|}{ Equal allocation to each manager } & 19.13 & 0.257 & 0.6684 & 74.436 \\
\hline \multicolumn{6}{|c|}{$\begin{array}{l}\text { Managers and Property type } \\
\text { Diversification }\end{array}$} \\
\hline \multicolumn{2}{|c|}{ 1. Equal to managers and property types } & 19.13 & 0.253 & 0.8406 & 75.613 \\
\hline \multicolumn{2}{|c|}{$\begin{array}{l}\text { 2. Equal to managers and allocation to } \\
\text { one property type in each manager's } \\
\text { portfolio (1) }\end{array}$} & 19.19 & 1.257 & 0.2446 & 15.267 \\
\hline --- Ditto --- & Portfolio 2 & 22.32 & 0.878 & 0.5171 & 25.421 \\
\hline --- Ditto --- & Portfolio 3 & 18.95 & 0.388 & 0.7856 & 56.065 \\
\hline --- Ditto --- & Portfolio 4 & 23.19 & 0.274 & 0.8713 & 84.635 \\
\hline --- Ditto --- & Portfolio 5 & 18.08 & 0.858 & 0.4276 & 21.072 \\
\hline --- Ditto --- & Portfolio 6 & 17.14 & 0.521 & 0.6023 & 32.898 \\
\hline --- Ditto --- & Portfolio 7 & 20.27 & 0.447 & 0.6947 & 45.347 \\
\hline --- Ditto --- & Portfolio 8 & 16.90 & 1.258 & 0.1366 & 13.434 \\
\hline --- Ditto --- & Portfolio 9 & 21.14 & 1.142 & 0.3570 & 18.511 \\
\hline --- Ditto --- & Portfolio 10 & 17.36 & 0.362 & 0.5891 & 47.956 \\
\hline --- Ditto --- & Portfolio 11 & 15.81 & 0.881 & 0.4406 & 17.946 \\
\hline --- Ditto --- & Portfolio 12 & 23.65 & 1.216 & 0.2170 & 19.449 \\
\hline --- Ditto --- & Portfolio 13 & 16.68 & 1.218 & 0.3545 & 13.695 \\
\hline
\end{tabular}

Eff. of Diversification = Effectiveness of Diversification

Table 3. Diversification by Managers (efficient portfolios)

\begin{tabular}{llllllll}
\hline Portfolios & $\begin{array}{l}\text { Portfolio } \\
\text { Return } \\
\left(R_{p}\right)\end{array}$ & $\begin{array}{l}\text { Standard } \\
\text { Deviation } \\
(\text { Std })\end{array}$ & $\begin{array}{l}\text { Eff. of } \\
\text { Diversifi- } \\
\text { cation }\end{array}$ & $\begin{array}{l}\text { Mean/Std } \\
\left(R_{p} / \delta\right)\end{array}$ & \multicolumn{2}{l}{ Percentage allocations } \\
\cline { 6 - 8 } & 21.96 & 1.154 & 0.4560 & 19.029 & 0.000 & 0.000 & 1.000 \\
\hline Corr. of +1.0 & 19.35 & 0.267 & 0.5876 & 72.472 & 0.349 & 0.291 & 0.360 \\
Corr. of +0.5 & 18.04 & 0.235 & 0.6206 & 76.766 & 0.246 & 0.543 & 0.211 \\
Corr. of +0.1 & 17.89 & 0.235 & 0.6067 & 76.128 & 0.234 & 0.572 & 0.194 \\
Corr. of -0.1 & 17.92 & 0.237 & 0.6065 & 75.612 & 0.236 & 0.566 & 0.198 \\
Corr. of -0.5 & 20.69 & 0.299 & 0.5460 & 69.197 & 0.545 & 0.000 & 0.455 \\
Corr. of -1.0 & & & & & & &
\end{tabular}

Note: A, B, C represent Managers A, B and C portfolios; Corr. = Correlation Coefficient. 
standard deviation ratio and effectiveness of diversification of diversification strategy by managers and property types are shown in Table 4. The dominant portfolio (in terms of mean standard deviation ratio) on this strategy is the portfolio that is based on -0.1 correlation coefficient. Although, this portfolio outperformed virtually all of the naive portfolios based on this strategy, it did not outperform the dominant naive portfolio and one other. Meanwhile, the range of returns on these portfolios is far less than the one achieved by the naive diversifications (2.27 vs 7.84$)$. It is also noted that the dominant efficient portfolio might have performed better than others tested because it invested in all the properties under the three managers' portfolios ( 8 in all) except one. Thus, there is more opportunity for better spread of assets and risk.

\subsection{Comparing the Dominant Strategies}

Table 5 compares the dominant naive strategies and the efficient set returns, standard

Table 4. Diversification by Manager and Property Ttypes (efficient portfolios):

\begin{tabular}{|c|c|c|c|c|c|c|c|c|c|c|c|c|}
\hline \multirow{2}{*}{$\begin{array}{l}\text { Port- } \\
\text { folios }\end{array}$} & \multirow{2}{*}{$\begin{array}{l}\text { Port- } \\
\text { folio } \\
\text { Re- } \\
\text { turn } \\
\left(R_{p}\right)\end{array}$} & \multirow{2}{*}{$\begin{array}{l}\text { Stand- } \\
\text { ard } \\
\text { Devia- } \\
\text { tion } \\
\text { (Std) }\end{array}$} & \multirow{2}{*}{$\begin{array}{l}\text { Eff. of } \\
\text { Diver- } \\
\text { sifi- } \\
\text { cation }\end{array}$} & \multirow{2}{*}{$\begin{array}{l}\text { Mean- } \\
\text { /Std } \\
\left(R_{p} / \delta\right)\end{array}$} & \multicolumn{8}{|c|}{ Percentage allocations } \\
\hline & & & & & $\mathrm{A}_{1}$ & $\mathrm{~A}_{2}$ & $\mathrm{~B}_{1}$ & $\mathrm{~B}_{2}$ & $\mathrm{~B}_{3}$ & $\mathrm{C}_{1}$ & $\mathrm{C}_{2}$ & $\mathrm{C}_{3}$ \\
\hline $\begin{array}{l}\text { Corr. } \\
\text { of }+1.0\end{array}$ & 23.75 & 0.891 & 0.000 & 26.655 & 0.000 & 0.000 & 0.000 & 0.00 & 0.00 & 0.000 & 1.000 & 0.000 \\
\hline $\begin{array}{l}\text { Corr. } \\
\text { of }+0.5\end{array}$ & 23.87 & 0.785 & 0.1910 & 30.408 & 0.000 & 0.000 & 0.000 & 0.160 & 0.00 & 0.840 & 0.00 & 0.000 \\
\hline $\begin{array}{l}\text { Corr. } \\
\text { of }+0.1\end{array}$ & 23.66 & 0.684 & 0.4121 & 34.591 & 0.042 & 0.000 & 0.000 & 0.252 & 0.00 & 0.631 & 0.048 & 0.027 \\
\hline $\begin{array}{l}\text { Corr. } \\
\text { of }-0.1\end{array}$ & 21.71 & 0.364 & 0.7431 & 59.643 & 0.082 & 0.121 & 0.054 & 0.192 & 0.00 & 0.368 & 0.112 & 0.071 \\
\hline $\begin{array}{l}\text { Corr. } \\
\text { of }-0.5\end{array}$ & 23.89 & 0.857 & 0.2545 & 27.876 & 0.079 & 0.000 & 0.000 & 0.284 & 0.00 & 0.637 & 0.000 & 0.000 \\
\hline $\begin{array}{l}\text { Corr. } \\
\text { of }-1.0\end{array}$ & 23.98 & 0.758 & 0.2738 & 31.636 & 0.000 & 0.000 & 0.000 & 0.308 & 0.00 & 0.692 & 0.000 & 0.000 \\
\hline
\end{tabular}

Note: $A_{1}, B_{1}, C_{1}$ e.t.c. Stand for property 1 in the portfolio of manager A, property 1 in the portfolio of manager $B$, and property 1 in the portfolio of manager $\mathrm{C}$ and so on.

Table 5. Dominant strategies

\begin{tabular}{|c|c|c|c|c|c|c|c|c|}
\hline & \multicolumn{4}{|c|}{ Naive Diversification } & \multicolumn{4}{|c|}{ Efficient Portfolios High Return } \\
\hline & $R_{p}$ & $\delta_{p}$ & $\mathrm{M} / \delta$ & $\begin{array}{l}\text { Eff. of } \\
\text { Div }\end{array}$ & $R_{p}$ & $\delta_{p}$ & $\mathrm{M} / \delta$ & $\begin{array}{l}\text { Eff. of } \\
\text { Div }\end{array}$ \\
\hline $\begin{array}{l}\text { Manager's } \\
\text { Diversification }\end{array}$ & 19.13 & 0.257 & 74.436 & 0.6684 & 18.04 & 0.235 & 76.766 & 0.6206 \\
\hline $\begin{array}{l}\text { Manager and Property } \\
\text { type }\end{array}$ & 23.19 & 0.274 & 84.635 & 0.8713 & 21.71 & 0.364 & 59.643 & 0.7431 \\
\hline
\end{tabular}

Eff. of Div = Effectiveness of Diversification 
deviations and their effectiveness of diversification for each of the two diversification strategies considered.

The results show that for managers diversification only, the strategy of equal allocation to all managers' portfolio achieved a higher return (19.13 vs 18.04) than the efficient frontier although with a higher risk level $(0.257$ vs 0.235 ). For managers and property type diversification, the strategy of equal allocation to all managers with the allocation invested in one property type in each manager's portfolio produced a superior return performance portfolio (portfolio that combines $\mathrm{A}_{1}, \mathrm{~B}_{2}$, and $\mathrm{C}_{3}$ ) than the corresponding efficient portfolio. It turns in a marginally superior return performance (23.19 vs 21.71) for even a lower risk than the efficient portfolios (0.274 vs 0.364$)$. The mean standard deviation ratio however shows slightly different results. While the dominant naive portfolio based on managers and property types diversification outperformed the efficient portfolio based on this strategy ( 84.635 vs 59.643 ), the dominant portfolio based on managers diversification only did not outperform the corresponding efficient portfolio (74.436 vs 76.766). The results of the effectiveness of diversification of the dominant strategies also reflect that the naive portfolios on the two strategies are better than their corresponding efficient portfolios. The strategies achieved effectiveness of diversification level of 0.6684 vs 0.6206 and 0.8406 vs 0.7431 for naive and efficient portfolios respectively. The study's analyses therefore suggest that diversification of managers and property types produce improved performance and that efficient portfolios may not, afterall, be superior to all naively diversified portfolios.

\section{CONCLUSION}

Our analysis of managers' diversification within Nigerian market during the period 1997- 2001 shows that efficient portfolios (con- stant correlation model portfolios) outperformed all strategies based on "all allocation in one property manager's portfolio" and the strategy based on "equal allocation to each of the managers". With regards to managers and property type diversification, efficient portfolios outperformed most, but not all, of those strategies based on "equal allocation between managers with the allocation to each manager invested in one property class". Also, efficient portfolios did not outperform the portfolio that was based on "equal allocation between managers with the allocation spread evenly among property type in each manager's portfolio". Thus, this result opens the possibility that an efficient portfolio developed by constant correlation analysis may not be more efficient than a naively diversified portfolio.

While we may attribute the finding in the study to the fact that assets are assumed to be held long (no short sale) the finding may vary if short selling is allowed. Also, the relatively high correlation assumed to be between pair of assets might have been disadvantageous to efficient portfolios in terms of the spread of assets and risk reduction. It has been noted earlier in the study that portfolio efficiency tends to increase with the reduction in the correlation coefficient.

Although, the study did not test the statistical significance of the benefits being found from managers' diversification and examine the effects of cycle on the performance of the portfolios, it has shown that there are benefits derivable from managers' diversification. For investors who therefore welcome every bit of risk reduction regardless of how slight the chance is, managers and property type diversification may be perceived as useful. Further research could be done to test the statistical significance of managers' diversification and can obtain additional evidence as to the ex ante performance of all those strategies tested in this study. In addition, the study can be extended further and enriched with additional property managers and property characteristics. 


\section{REFERENCES}

Adair, A., McGreal, S. and Webb, J. R. (2006) Diversification Effects of Direct versus Indirect Real Estate Investments in the U.K. Journal of Real Estate Portfolio Management, 12(2), p. 85-90.

Ajala, O. O. (2001) Comparison of Portfolio Performance In Corporate Public and Private Firms: A Case Study of UACN Property Development Company PLC and Wemabod Estate Limited, B.Sc Dissertation of the Department of Estate Management, Obafemi Awolowo University, IleIfe.

Ajayi, C. A. (1998) Property Investment and Analysis, De-Ayo Publications, Ibadan.

Brown, G. R. (1997) Reducing the Dispersion of Returns in U.K. Real Estate Portfolios. Journal of Real Estate Portfolio Management, 3(2), p. 129-140.

Brown, R., Li, L. H. and Lusht, K. (2000) A Note on Intracity Geographic Diversification of Real Estate Portfolios: Evidence from Hong Kong. Journal of Real Estate Portfolio Management, 6(2), p. 131-140.

Cheng, P. and Liang, Y. (2000) Optimal Diversification: Is It Really Worthwhile? Journal of Real Estate Portfolio Management, 6(1), p. 7-16.

Conover, M., Friday, S. and Sirmans, S. (2002) Diversification Benefits from Foreign Real Estate Investment. Journal of Real Estate Portfolio Management, 8(1), p. 17-26.

Del Casino, J. J. (1995) Portfolio Diversification Considerations, In Pagliari, J. L. (Jr) (ed), The Handbook of Real Estate Portfolio Management, IRWIN, Chicago, pp. 912-966.

Elton, E. J. and Gruber, M. J. (1981) Modern Portfolio Theory and Investment Analysis, John Wiley \& Sons, New York.

Geltner, D. M. (1991) Smoothing in Appraisal-Based Returns. Journal of Real Estate Finance and Economics, 4(4), p. 327-345.

Giliberto, M. and Hopkins, R. E. (1990) Metro Employment Trends: Analysis and Portfolio Considerations, Salomon Brothers Inc. May 14.

Grissom, T. V., Kuhle, J. L. and Walther, C. H. (1987) Diversification Works in Real Estate Too. Journal of Real Estate Portfolio Management, 13(2), p. 66-67.

Hadaway, S. C. (1978) Diversification Possibilities in Agricultural Land Investments. The Appraisal Journal, p. 529-537.

Hargitay, S. E. and Yu, S. (1993) Property Investment Decisions: A Quantitative Approach, E\&FN Spon, New York.

Hartzell, D. J., Hekman, J. S. and Miles, M. E. (1986) Diversification Categories in Investment Real Estate. AREUEA Journal, 14(2), p. 230254.

Hartzell, D. J., Shulman, D. G. and Wurtzebach, C. H. (1987) Refining the Analysis of Regional Diversification for Income-Producing Real Estate. Journal of Real Estate Research, 2(2), p. 85-95.

Lee, S. L. (2005) The Return Due to Diversification of Real Estate to the U.S. Mixed-Asset Portfolio. Journal of Real Estate Portfolio Management, 11(1), p. 19-28.

Lee, S. and Stevenson, S. (2005) Testing the Statistical Significance of Sector and Regional Diversification. Journal of Property Investment and Finance, 23(5), p. 394-411.

Liow, K., Ooi, J. and Gong, Y. (2005) Cross Market Dynamics in Property Stock Markets: Some International Evidence. Journal of Property Management and Finance, 22(5), p. 401-413.

Markowitz, H. M. (1952) Portfolio Selection. Journal of Finance, 3, p. 77-91.

Markowitz, H. M. (1959) Portfolio Selection: Efficient Diversification of Investments, John Wiley $\&$ Sons, New York.

Miles, M. E. and McCue, T. E. (1982) Historic Returns and Institutional Real Estate Portfolio. AREUEA Journal, 10(2), p. 184-198.

Mueller, G. R. (1993) Refining Economic Diversification Strategies for Real Estate Portfolios. Journal of Real Estate Research, 8(1), p. 5568.

Olaleye, A. (2000) A Study of Property Portfolio Management Practice in Nigeria, Unpublished M.Sc Dissertation of the Department of Estate Management, Obafemi Awolowo University, IleIfe.

Pagliari, J. L. (Jr), Webb, J. R. and Del Casino, J. J. (1995) Applying MPT to Institutional Real estate Portfolios: The Good, the Bad and the Uncertain. Journal of Real Estate Portfolio Management, 1(1), p. 67-88.

Viezer, T. W. (2000) Evaluating Within Real Estate Diversification Strategies. Journal of Real Estate Portfolio Management, 6(1), p. 75-95. 


\section{SANTRAUKA}

\section{NEKILNOJAMOJO TURTO PORTFELIŲ VALDYTOJŲ DIVERSIFIKACIJOS VERTINIMAS: İRODYMAI IŠ NIGERIJOS}

\section{Abel OLALEYE, Bioye Tajudeen ALUKO}

Nors yra įrodymų, kad geografinè nekilnojamojo turto portfelio diversifikacija arba diversifikacija pagal nuosavybės rūšis yra efektyvi, trūksta empirinių duomenų, patvirtinančių, kad verta siekti valdytojų diversifikacijos. Šis tyrimas pateikia įrodymų, kad valdytojų diversifikacija ir diversifikacija pagal nuosavybès rūšis yra efektyvi. Tyrimo metu surinkti duomenys apie kapitalą ir metines nuomos vertes iš trijų pagrindinių Lagoso miesto (Nigerija) nuosavybejs investicijų ir plètros bendrovių. Pagal surinktus duomenis apskaičiuota 1997-2001 metų metinè bendroji grąža (vidinė grąžos norma) iš valdytojų portfelyje esančios gyvenamosios nuosavybės. Tariant, kad investicijos ilgalaikès, o pastovios koreliacijos modelis arba perteklinès grąžos ir standartinès deviacijos santykis sudaro turto grąžos kovariancinę struktūrą, tyrimo metu atlikta analizė rodo, kad valdytojų ir nuosavybès rūšiu diversifikacija leidžia padidinti rezultatyvumą. Be to, analizės metu pastebèta ir tai, kad naudojant pastovios koreliacijos analizę suformuotas efektyvus portfelis gali būti né kiek ne efektyvesnis už paprastai diversifikuotą portfelį, nes paaiškèjo, kad kai kuri paprastosios diversifikacijos strategija yra labai efektyvi. 